\title{
Combination of exercise and caloric restriction ameliorates nearly complete deleterious effects of aging on cardiovascular hemodynamic and antioxidant system parameters
}

\author{
Çağlar MACIT 1 * (D), Ünsal V. ÜSTÜNDAG ${ }^{2}$ (D), Ozan E. EYÜPOĞLU 3 (D), Özge DAĞDEVİREN-ÇEVIK 3 (D), \\ Göksel ŞENER 4 (D)
}

1 Department of Pharmacology, School of Pharmacy, İstanbul Medipol University, İstanbul, Turkey.

2 Department of Biochemistry, School of Medicine, İstanbul Medipol University, İstanbul, Turkey.

3 Department of Biochemistry, School of Pharmacy, İstanbul Medipol University, İstanbul, Turkey.

4 Department of Biochemistry, Faculty of Medicine, Adnan Menderes University, Aydın, Turkey.

5 Department of Pharmacology, School of Pharmacy, Marmara University, İstanbul, Turkey.

* Corresponding Author. E-mail: cmacit@medipol.edu.tr (Ç.M.); Tel. +90-533-655 4591.

Received: 18 June 2019 / Revised: 07 October 2019/ Accepted: 22 October 2019

ABSTRACT: Aging is a progressive and catabolic process by cells of the body are broken down. Study scrutinized the effects of exercise and caloric restriction in cardiovascular hemodynamics and antioxidant system parameters. Rats divided to 5 categories as 1 control group (including 3 months aged animals) and 4 test groups (including 15 months aged animals) named by A-SED (aged-sedentary), A-CR (aged-caloric restricted), A-EX (aged-exercised) and A-CR-EX (aged-(exercised + caloric restricted)) created by adding carbachol (CAR) and phenylephrine (PE) cumulatively and during 6 weeks, $40 \%$ caloric restriction and swimming were administered to aged animals. At the beginning and end of study, blood pressure (BP) and ECHO of the animals were measured. After decapitation process, tissue (heart and aorta) samples were collected. In tissue samples, apoptotic and oxidative stress parameters, and in blood samples NO levels were studied. Additionally, tissues were viewed as histologically at light microscopy. GraphPad Prism 5v. program was used for statistics and $\mathrm{p}<0.05$ were considered significantly. Contraction-relaxation responses of aorta improved after CR and EX administrations $(\mathrm{p}<0.05)$. In both tissues, oxidative stress parameters (8-OHdG, MDA, SOD, GSH), caspase-3 activity and caspase-3 dansity were recovered meaningfully $(p<0.05)$. Finally, NO levels were significantly recovered with CR and EX administrations in aged animals $(p<0.05)$. To sum up, it is suggested that $C R$ and EX administrations contribute to the recovery of hemodynamic and antioxidant system parameters in aged rats.

KEYWORDS: Aging; caloric restriction; oxidative stress; exercise; cardiovascular hemodynamics.

\section{INTRODUCTION}

Aging is an inevitable and foreseeable process and prevention of aging with antioxidant supplements is a study area that scientists have been working on for long decades [1]. Some of them are irreversible while some others are not. Alterations in antioxidant system and cardiovascular system are considered as reversible. Recent studies showed oxidative stress and free increased production of reactive oxygen species (ROS) had key role for development of these alterations [2].

Scientists produced hundreds of novel hypotheses about aging to prevent senescence, oxidative stress and ROS production and improve lifestyle beside pharmacological treatments [3,4]. Caloric restriction and exercise are considered as the most beneficial ones. Caloric restriction (CR) and exercise (EX) are suggested to reverse these changes occurred in aging process. Both has been well known to provide benefits against cardiovascular hemodynamic and oxidative stress parameters via increasing bioavailability of nitric oxide (NO) levels and decreasing of ROS.

In the view of these studies, it has known that caloric restriction or exercise is enough to improve aged related deteriorations. However, we think that combined applications of CR and EX will provide better recovery in both cardiovascular hemodynamic and oxidative stress parameters.

How to cite this article: Macit Ç, Üstündağ Ünsal V, Eyüpoğlu OE, Dağdeviren-Çevik Ö, Şener G. Combination of exercise and caloric restriction ameliorates nearly complete deleterious effects of aging on cardiovascular hemodynamic and antioxidant system parameters. J Res Pharm. 2020; 24(1): 121-132. 


\section{RESULTS AND DISCUSSION}

\subsection{Cardiovascular hemodynamic}

As we know, worsening of BP, left ventricular diameter (LVD) and risk for CVD were associated with endothelial dysfunction. Alterations of these parameters were minimized or returned by CR and EX. Several studies have showed beneficial effects of short-term CR and EX for reversing of these changes [16-20]. The human body also accumulates ROS that lead to tissue damage and decreased cardiovascular hemodynamic. For instance, left ventricular diameter (LVD) becomes thick. CR and EX play important role on LVD via providing reduction of neurohormones in circulation and by increasing GSH levels [21,22]. At the end of study, our results show consistency with other studies that CR and EX significantly improved BP, left ventricular diameter in systole (LVDs) and diastole (LVDd) and ejection fraction (EF) values recovered at $t_{2}$ when compared with $t_{1}$ in the investigation groups when compare to sedentary aged animals $(p<0.001)$. Changes in cardiovascular parameters were summarized in Figures 1, 2, 3, and 4, respectively.

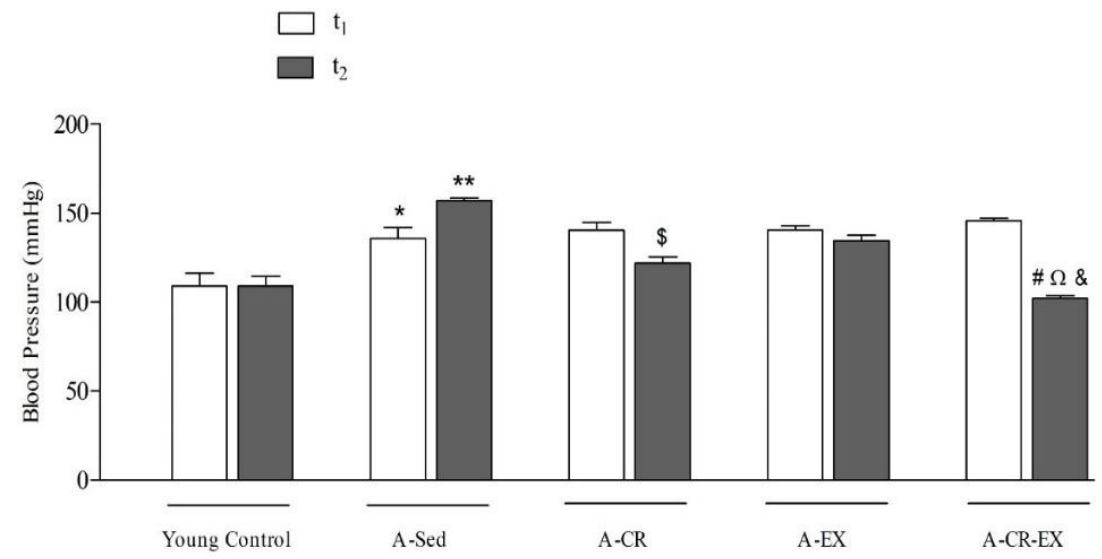

Figure 1. Blood pressure changes of the intervention groups. Young Control: 3 month-aged young animals; A-SED: 15 month-aged and sedentary animals; A-CR: 15 month-aged and 6 weeks CR administered animals; A-EX: 15 month-aged and 6 weeks EX administered animals; A-CR-EX: 15-month-aged and 6 weeks CR and EX administered animals. $\mathrm{t} 1$ : beginning of experiment; $\mathrm{t} 2$ : end of the experiment; *: Young Control $\mathrm{t} 1$ and $\mathrm{t} 2$ compared to A-Sed t2; **: A-Sed $\mathrm{t} 1$ compared to A-Sed t2; \#: A-CR-EX t1 compared to A-CR-EX t2; ?: A-Sed t2 compared to A-CR-EX t2; $\Omega$ : A-CR t2 compared to A-CR-EX t2; \&: A-EX t2 compared to A-CR-EX t2. Oneway ANOVA followed by both Tukey's and Bonferroni's post hoc tests $(\mathrm{p}<0.05)$.

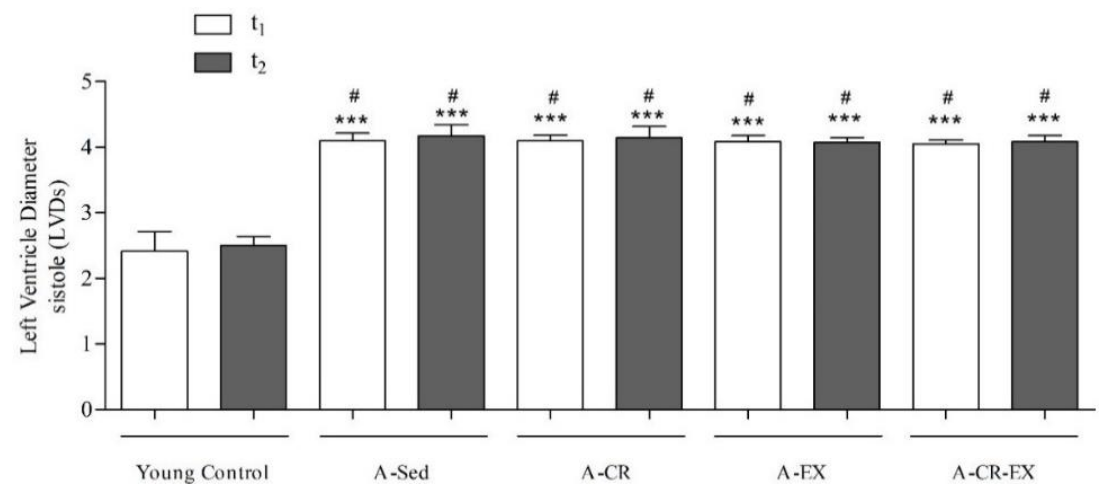

Figure 2. Changes in the Left Ventricle Diameter at systole (LVDs) of the intervention groups. Young Control: 3 month-aged young animals; A-SED: 15 month-aged and sedentary animals; A-CR: 15 month-aged and 6 weeks CR administered animals; A-EX: 15 month-aged and 6 weeks EX administered animals; A-CREX: 15-month-aged and 6 weeks CR and EX administered animals. t1: beginning of experiment; $\mathrm{t} 2$ : end of the experiment; ${ }^{* * *}$ : Young Control $\mathrm{t} 1$ compared to all other groups; \#: Young Control t 2 compared to all other groups. One-way ANOVA followed by both Tukey's and Bonferroni's post hoc tests $(\mathrm{p}<0.001)$. 


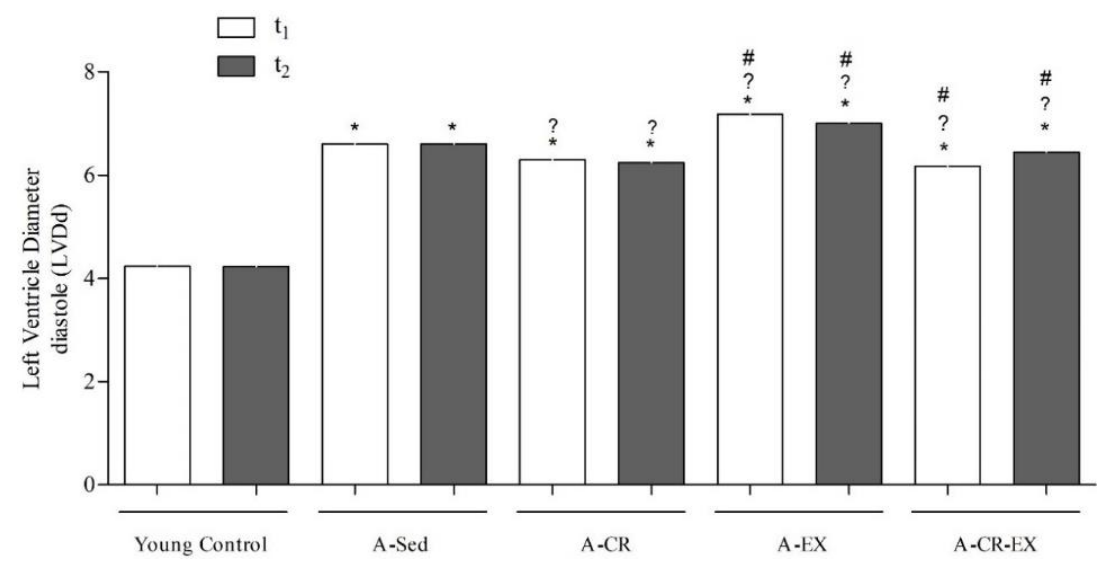

Figure 3. Changes in the Left Ventricle Diameter at diastole (LVDd) of the intervention groups. Young Control: 3 month-aged young animals; A-SED: 15 month-aged and sedentary animals; A-CR: 15 month-aged and 6 weeks CR administered animals; A-EX: 15 month-aged and 6 weeks EX administered animals; A-CREX: 15-month-aged and 6 weeks CR and EX administered animals. t1: beginning of experiment; $\mathrm{t} 2$ : end of the experiment; *: Young Control $t 1$ and $t 2$ compared to all other groups; ?: A-Sed $t 1$ and $t 2$ compared to all other groups; \#: A-CR-EX t1 and $\mathrm{t} 2$ compared to all other groups. One-way ANOVA followed by both Tukey's and Bonferroni's post hoc tests $(\mathrm{p}<0.001)$.

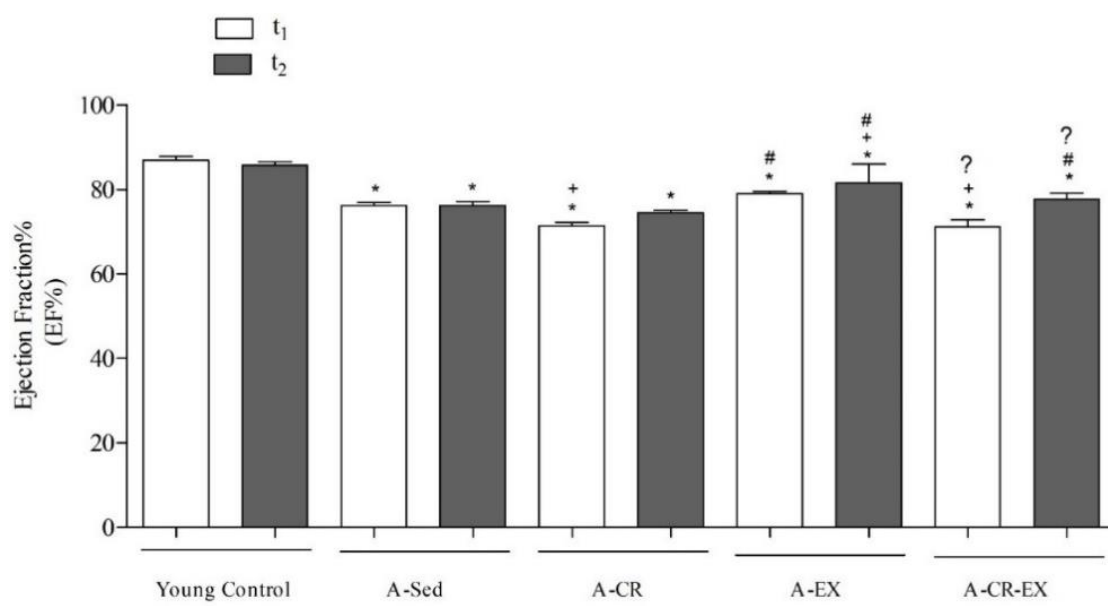

Figure 4. Ejection Fraction (EF\%) changes of the intervention groups. Young Control: 3 month-aged young animals; A-SED: 15 month-aged and sedentary animals; A-CR: 15 month-aged and 6 weeks CR administered animals; A-EX: 15 month-aged and 6 weeks EX administered animals; A-CR-EX: 15-month-aged and 6 weeks CR and EX administered animals. t1: beginning of experiment; $\mathrm{t} 2$ : end of the experiment; *: Young Control $t 1$ and $t 2$ compared to all other groups; +:A-Sed $t 1$ and $t 2$ compared to A-CR $t 1, A-E X$ t2 and A-CREX $t 1$ groups; \#: A-CR $t 1$ and $t 2$ compared to A-EX $t 1$ and $t 2$ and A-CR-EX $t 2$ groups; ?: A-CR-EX $t 1$ and $t 2$ compared to A-EX $t 1$ and 2 groups. One-way ANOVA followed by both Tukey's and Bonferroni's post hoc tests $(\mathrm{p}<0.001)$.

\subsection{Isolated tissue bath study in aorta and NO levels in blood}

As it is well known, aging and related disease like hypertension reduce endothelial dysfunction by impairing NO bioavailability [23, 24]. There have been many studies showed short term CR and EX improved endothelial function by significantly increasing NO bioavailability and arteries gave better contractionrelaxation responses in aged animals [25-27]. Furthermore, it was shown that regular administration of caloric restriction prevents endothelial senescence [28].

Results of our isolated tissue bath study and NO levels in blood samples showed consistency with findings of other previous studies. Interventional rats showed better contractions at the end of the experiment when compared with aged sedentary group. Results were given in Table 1 and Figure 5, separately. Additionally, Figure 6 showed that serum NO levels significantly reduced in A-SED group when compared to young control $(p<0.001)$. After administrations of CR and EX serum NO levels increased meaningfully in the study groups $(\mathrm{p}<0.001)$. 
Table 1. $\mathrm{EC}_{50}$ values for phenylephrine (PE) and carbachol (CAR) in aortic rings.

\begin{tabular}{lccccc}
\hline EC $_{50}$ & Control & A-SED & A-CR & A-EX & A-CR-EX \\
\hline Phenylephrine & $5.2 \times 10^{-7}$ & $1.1 \times 10^{-6}$ & $2.2 \times 10^{-6}$ & $1.8 \times 10^{-6}$ & $1.2 \times 10^{-6 *}, \&$ \\
Carbachol & $3.6 \times 10^{-7}$ & $6.3 \times 10^{-7^{* * *}}$ & $5.5 \times 10^{-7 * *}$ & $6.6 \times 10^{-7^{* *}}$ & $3.8 \times 10^{-7^{*},++, \&, \#}$ \\
\hline
\end{tabular}

One-way ANOVA followed by Bonferroni's post hoc test $(\mathrm{p}<0.05)$.

${ }^{*} \mathrm{p}<0.05,{ }^{* *} \mathrm{p}<0.01$,

$p<0.001$ compared to control group

${ }^{++} \mathrm{p}<0.01$ compared to A-SED group;

$\& p<0.05$ compared to A-CR group;

\# $\mathrm{p}<0.05$ compared to A-EX group.
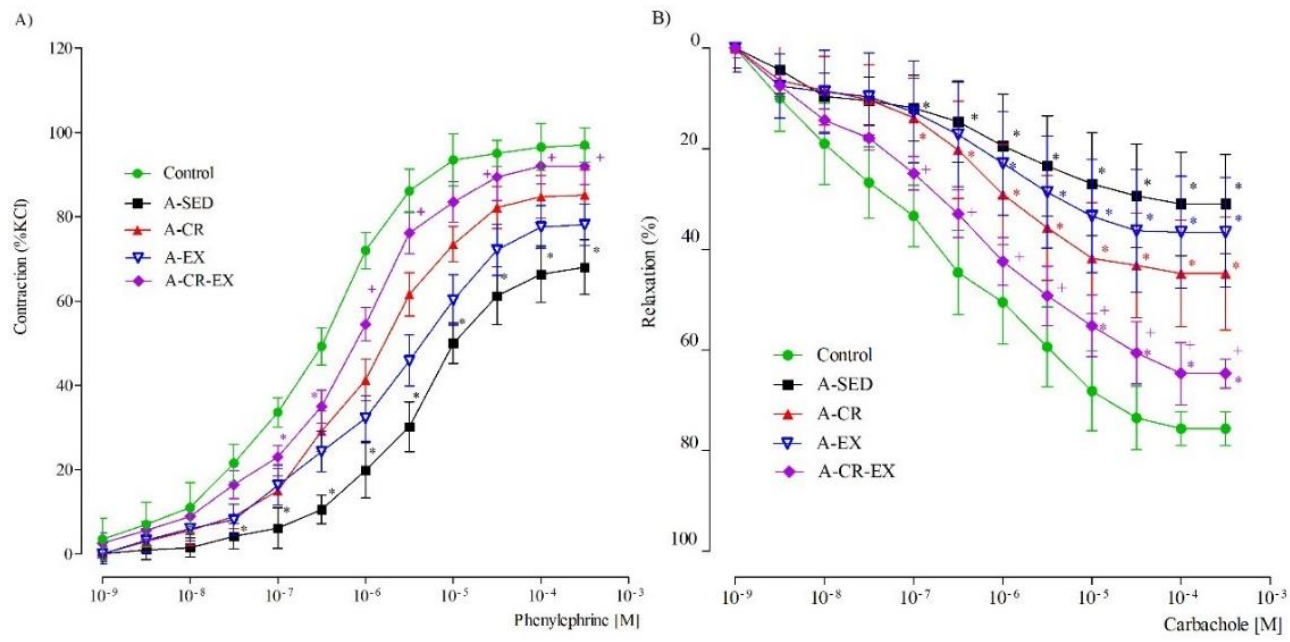

Figure 5. Concentration-response curves obtained by cumulative addition of phenylephrine (PE) and carbachol (CAR) to rat aortic rings. A-CR ${ }^{\mathbf{}}$ : 15 month-aged and 6 weeks CR administered animals; A-CREX $\bullet:$ : 15-month-aged and 6 weeks CR and EX administered animals; A-SED - : 15 month-aged and sedentary animals; A-EX ${ }^{-\nabla}: 15$ month-aged and 6 weeks EX administered animals; Control $\bullet-: 3$ monthaged young animals. ${ }^{*} p<0.05$ compared to control group; $+p<0.05$ compared to A-SED group. One-way ANOVA followed by Tukey's post hoc test $(\mathrm{p}<0.05)$.

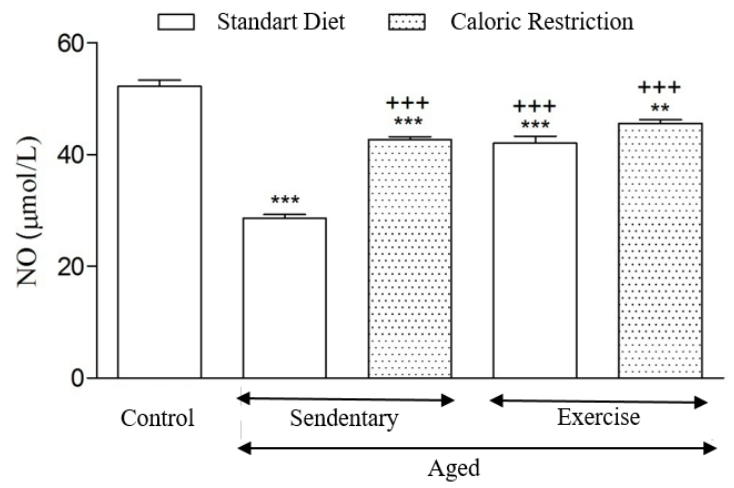

Figure 6. Effect of caloric restriction and exercise and both administrations of them on serum NO levels of study groups. ${ }^{* * *} \mathrm{p}<0.001$ compared to control group, ${ }^{+++} \mathrm{p}<0.001$ compared to A-SED. One-way ANOVA followed by Bonferroni's post hoc test $(p<0.05)$.

\subsection{Biochemical measurements in heart and aorta tissues}

Glutathione (GSH) is a substrate of some antioxidant enzymes. It is a non-enzymatic antioxidant protective system that cleans the HO and singlet $\mathrm{O}_{2}$. Deficiency of GSH in the body can leads to haemolysis like serious effect. Super oxide dismutase (SOD) is a critical enzymatic antioxidant that plays a key role in detoxification of superoxide. While aging process, like other protective mechanisms SOD level also reduced 
in the body. In order to prevent this decrement caloric restriction and exercise can be suggested. According to the findings previously reported that EX enhanced antioxidant enzyme SOD in aged rats [29]. Additionally, the studies also showed EX and CR raised the levels of antioxidant enzymes like SOD and GSH similar to other studies [30,31]. Because of these, exercise and caloric restriction are the most popular alternative therapies. They can be used as protective against aging and other related diseases, in combination with pharmacologic therapy or alone. In our study, GSH activity in aorta tissue of all study groups increased significantly $(\mathrm{p}<0.001)$ with applications of exercise and caloric restriction, simultaneously. On the other hand, aorta GSH level was higher in A-EX rats than both A-CR groups similar with a previous study that reported moderate reduction or no change in the GSH:GSSG ratio, usually [32]. Moreover, in heart and aorta tissues of aged rats, SOD enzyme activity increased significantly with alone and combined applications of CR and EX when compared with SOD enzyme activity level of aged-sedentary rats $(\mathrm{p}<0.001)$. It can be seen in Figure 7.

$$
\square \text { Standart Diet } \quad \text { Caloric Restriction }
$$

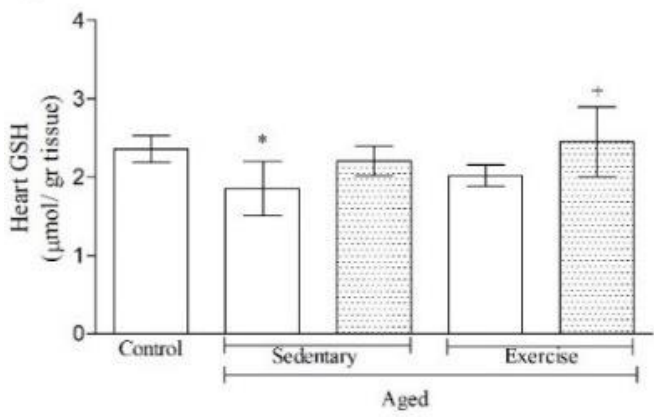

c)

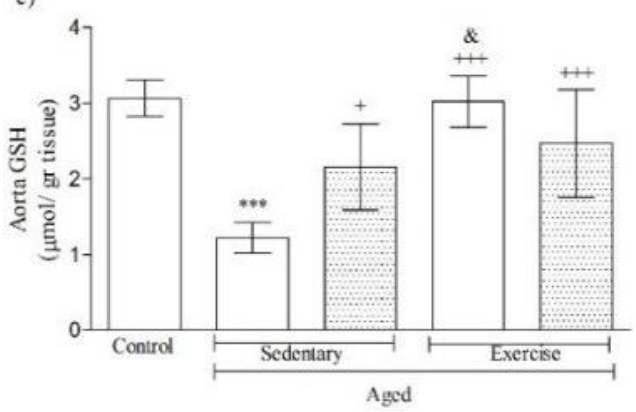

b)

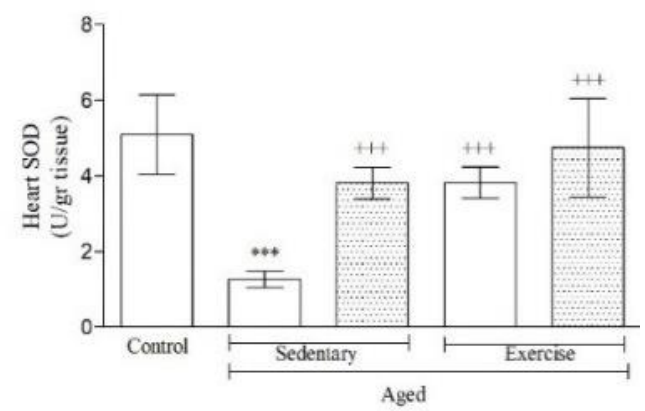

d)

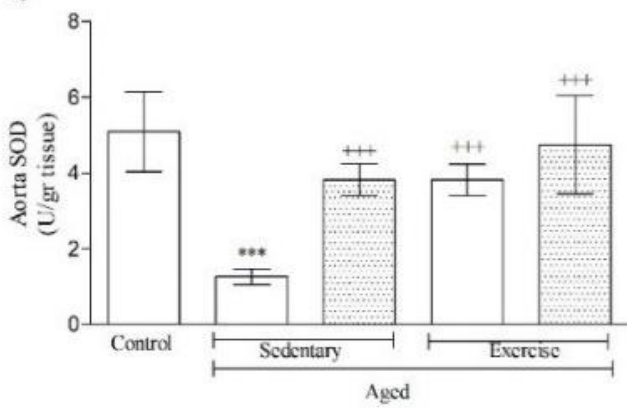

Figure 7. GSH and SOD levels in heart and aorta tissues of aged animals. ${ }^{*} \mathrm{p}<0.05,{ }^{* * *} \mathrm{p}<0.001$ compared to control group; $+\mathrm{p}<0.05,+++\mathrm{p}<0.001$ compared to A-SED; \& $<<0.05$ compared to A-CR group. One-way ANOVA followed by Bonferroni's post hoc test $(\mathrm{p}<0.05)$.

8-OHdG and MDA are indicators of oxidative damage in the cell and ROS production and as we all know that oxidative damage increases with getting older. Studies showed oxidative damage was attenuated by CR. As a result, plasma 8-OHdG level increased significantly [33, 34]. Furthermore, short-term EX also improved MDA and 8-OHdG levels in aged animals [35,36]. On the contrary, in a study done with rats which exposed to high-intensity exercise, plasma 8-OHdG level increased. In the view of this study, scientists revealed the importance of frequency of exercise [37]. Findings indicated that CR and EX play key role in normalization of endothelial function and improvement of GSH, SOD, MDA, 8-OHdG and apoptotic parameter levels [38]. We reported that CR and EX showed significant improvements in level of MDA and 8OHdG levels in heart and aorta tissues. 8-OHdG level in aged-sedentary rats of heart and aorta tissues was found as increased. According to the end-point results, short-term CR and moderate EX provided positive effects in 8-OHdG levels, significantly $(\mathrm{p}<0.01)$. Enzymatical activity of MDA was detected as raised in both of heart and aorta tissues of aged and sedentary animals when compared with young controls. On the other hand, this level was recovered significantly in both tissues (dramatically in aorta; $\mathrm{p}<0.001$ ) of all experimental groups by the administration of CR and EX (Figure 8). 
a)

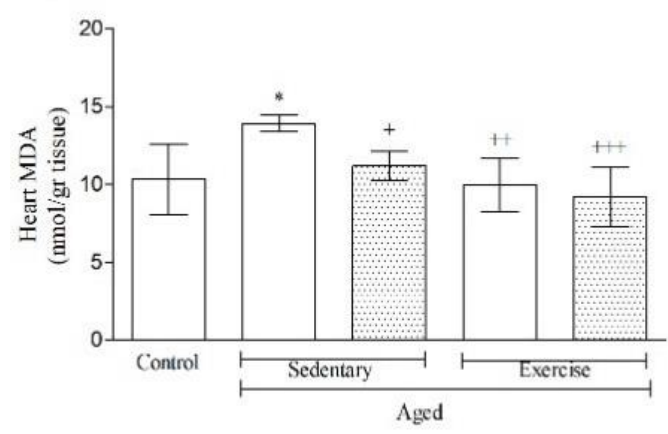

c)

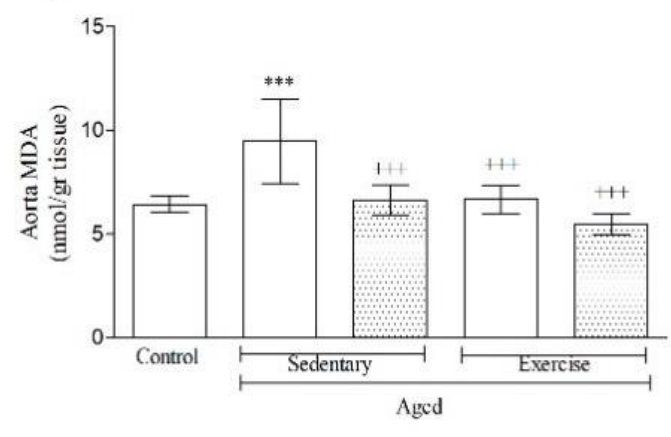

b)

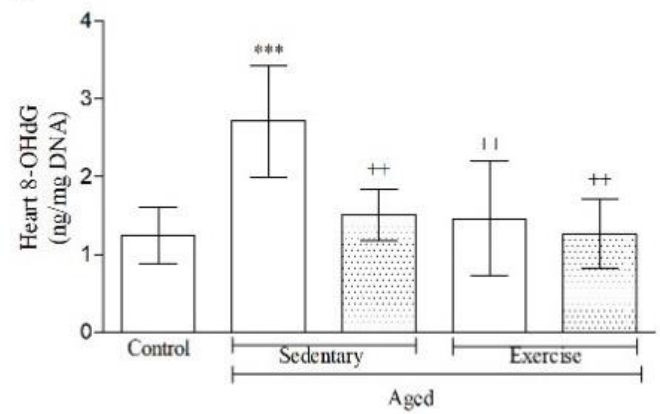

d)

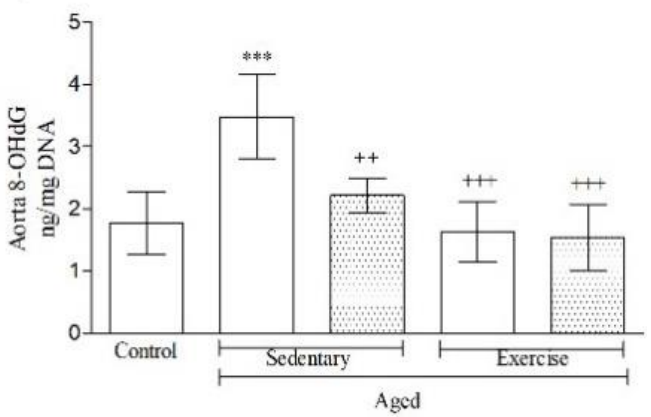

Figure 8. MDA and 8-OHdG levels in heart and aorta tissues of aged animals. ${ }^{*} \mathrm{p}<0.05,{ }^{* * *} \mathrm{p}<0.001$ compared to control group; $+p<0.05,++p<0.01,+++p<0.001$ compared to A-SED. One-way ANOVA followed by Bonferroni's post hoc test $(\mathrm{p}<0.05)$.

Furthermore, plenty of studies indicated that CR and EX have had regulatory effects on caspase-3 activity and dansity in aged animals [38, 39]. Caspase-3 activity was found as reduced in animals with lifelong CR when compared with sedentary animals [40]. As shown in Figure 9, our results were similar with literatures done before that caspase- 3 dansity and activity were reduced in heart and aorta tissues by the alone and in combined administration of CR and EX.

\subsection{Histological findings}

Aging is a progressive and catabolic process that all cells of the body are broken down. Furthermore, regeneration ability of the cells also reduced. As a result, both structures and morphology of the cells become impaired. In our study, morphology of the aorta and heart tissues of aged rats have become degenerated. On the other hand, CR and EX administered groups showed healing in the morphology of the muscle cells of aorta and heart. Like our study, one study [41] showed that caloric restriction reduced the attenuation of the morphology of heart and aorta in the aged rats.

Morphologies of both tissues in young control group were obtained normal (Fig 10A and 11A). As shown in Figure 10B and 11B, both aorta and heart tissues of the animals in aged sedentary group were examined as degenerated. CR and EX recovered degeneration in the muscle cells of heart and in the smooth muscle cells of aorta (Fig 10C and 11C; 10D and 11D). Finally, Figure 10E and Figure 11E illustrate that morphology of tissues in study group with combined administrations showed similarity to young control.

\section{CONCLUSION}

Taken together, the results show that caloric restriction and exercise administrations recover the cardiovascular hemodynamic, and contraction ability of aorta in aged animals. These effects are revealed through the enhancement of NO bioavailability, reduction of ROS production and decreasing of the apoptotic mechanisms. To sum up, to enhance NO and antioxidant capacity of body caloric restriction and exercise are the best known non-pharmacological approaches and our results also support this theory. 
$\square$ Standart Diet

a)
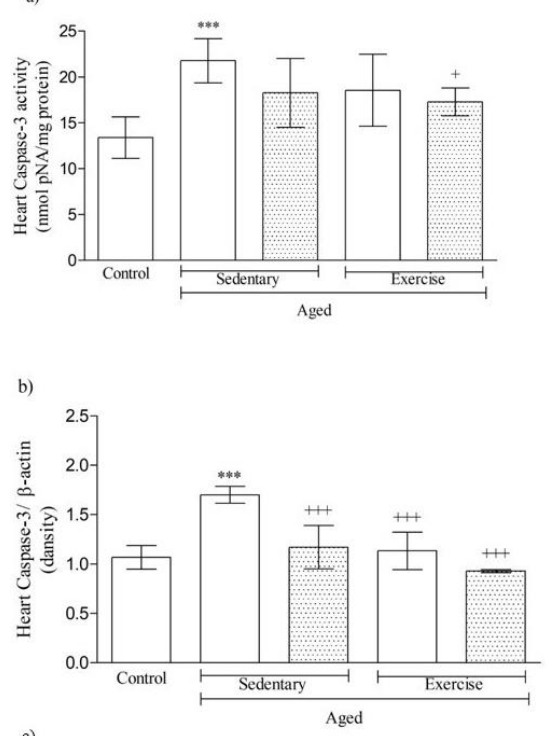

c)

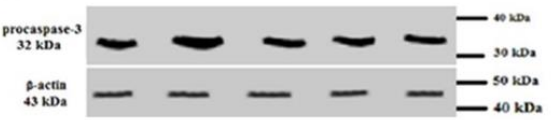

d)
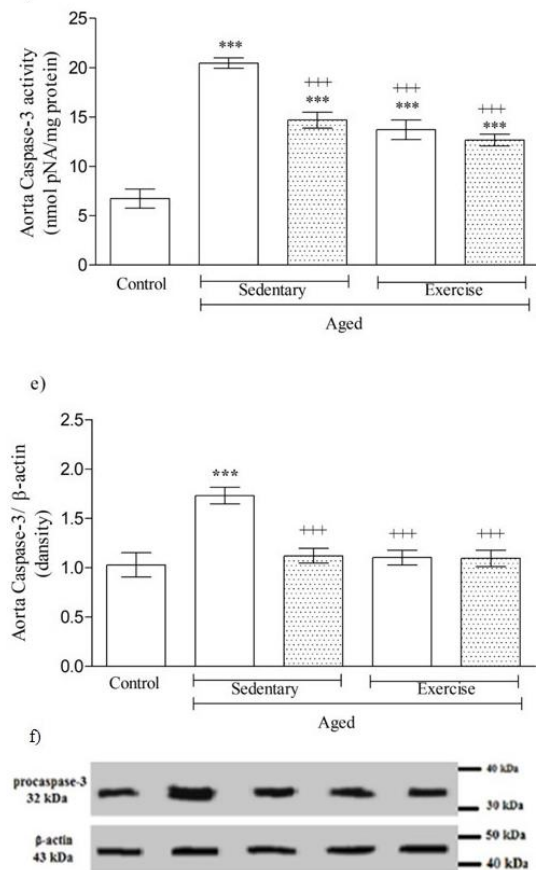

Figure 9. Changes in apoptotic parameters in heart and aorta tissues of aged animals, respectively, a: Caspase-3 activity, b: Caspase-3 dansity, c: Western blotting of procaspase-3 in heart tissue and d: Caspase3 activity, e: Caspase- 3 dansity, f: Western blotting of procaspase- 3 in aorta tissue. ${ }^{* * *} \mathrm{p}<0.001$ compared to control group; $+p<0.05,+++p<0.001$ compared to A-SED group. One-way ANOVA followed by Bonferroni's post hoc test $(\mathrm{p}<0.05)$.
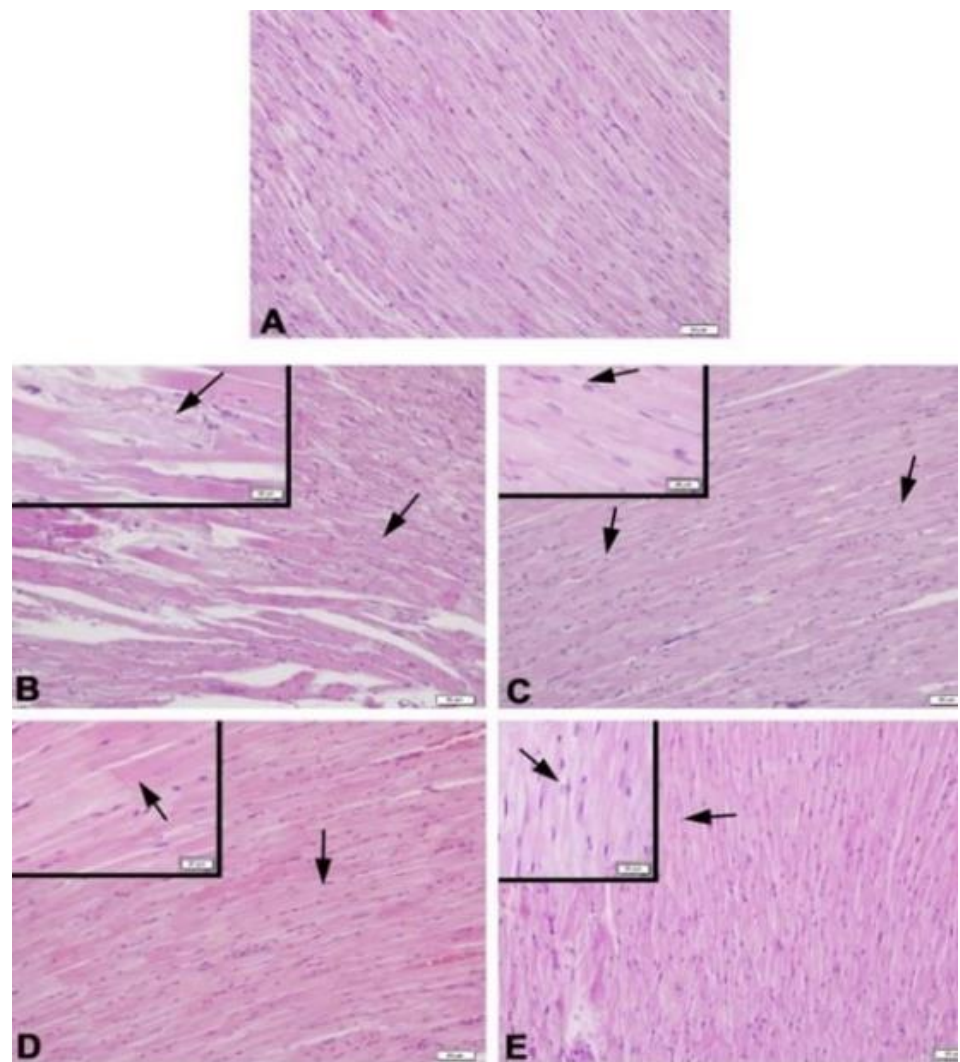

Figure 10. Histological improvements in heart. Striated muscle cell (arrow). H\&E staining, scale bars: $50 \mu \mathrm{m}$ and inset: $20 \mu \mathrm{m}$. 


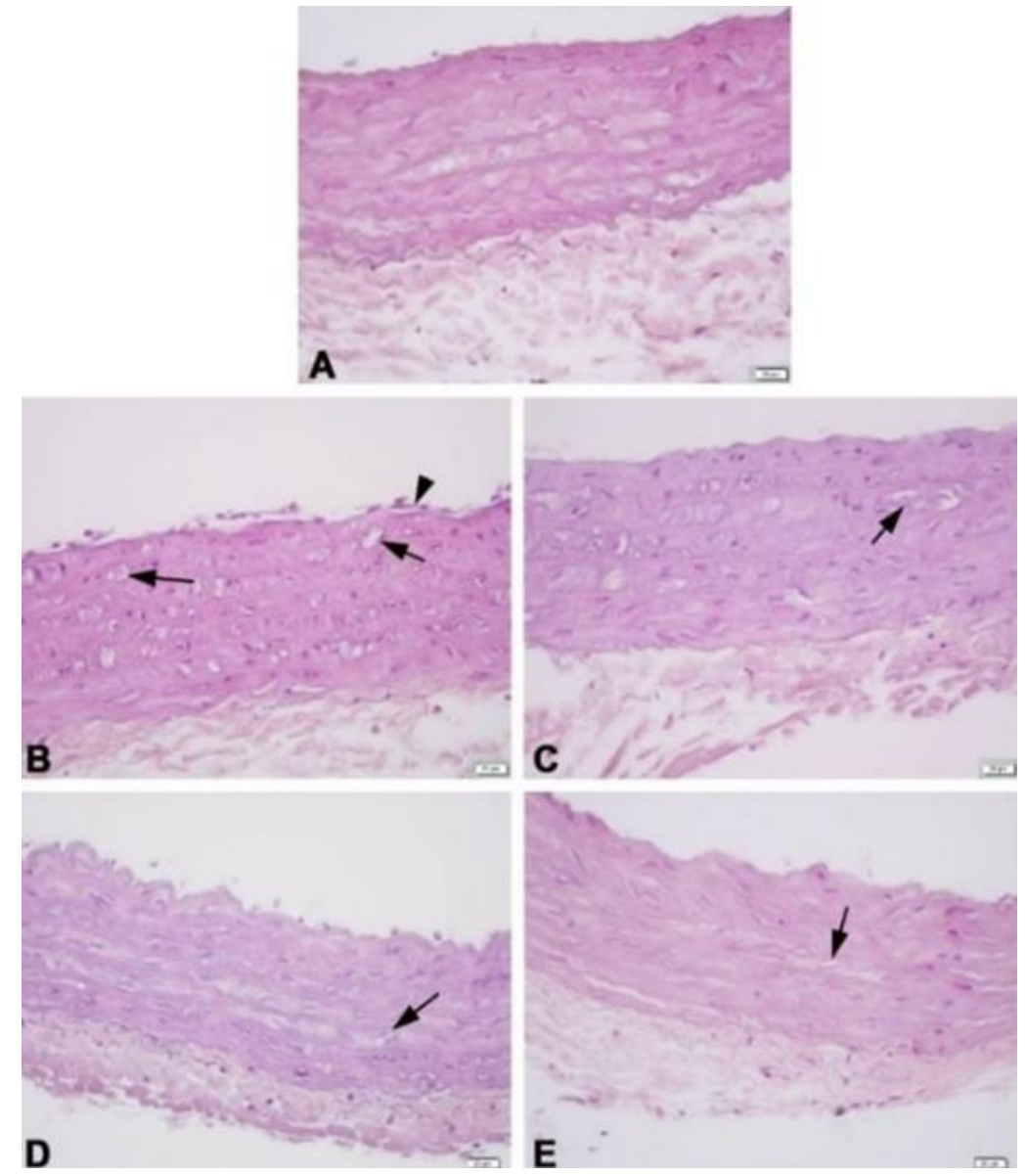

Figure 11. Histological changes in aorta ring of aged animal. Endothelial cell (arrowhead), smooth muscle cell (arrow). H\&E staining, scale bars: $50 \mu \mathrm{m}$ and inset: $20 \mu \mathrm{m}$.

\section{MATERIALS AND METHODS}

\subsection{Animals and experimental design}

56 Sprague-Dawley male rats $(15$-months aged, $n=48$; 3 -months aged, $n=8)$ were obtained from Marmara University Experimental Animals Laboratory. Randomly grouped aged animals were named by aged sedentary (A-SED), aged caloric restricted (A-CR), aged exercised (A-EX) and aged exercised + caloric restricted $(\mathrm{A}-(\mathrm{EX}+\mathrm{CR}))$ that each group had 12 rats. Remained animals were used as young control. Animals were acclimated 2 weeks. During experiment period, rats were also kept in a balanced temperature $\left(22 \pm 2{ }^{\circ} \mathrm{C}\right)$ and 12:12 h light-dark cycle. They were given tap water and ad libitum except CR study groups (CR=40\% of $a d$ libidum). Rat nutrient, Optima-23 composed of pure protein $23 \%$, pure fat $\% 5.5 \%$, pure cellulose $3.5 \%$, NDF $11 \%$, pure ash $8 \%$, lysine $1.35 \%$, methionine $0.45 \%$, cystine $0.35 \%$, Ca $1 \%$, Phosphate $0.75 \%$, Vit. A $18000 \mathrm{IU} / \mathrm{kg}$, Vit. D $3500 \mathrm{IU} / \mathrm{kg}$, Vit. E mg/ kg, with $12 \mathrm{~mm}$ of pellet diameter, and was purchased from Arden Research \& Experiment, Ankara. The CR (\%40 of ad libitum) [5] and EX (swimming 30 minutes, 3 times per a week) [6, 7, 8] procedures were administered to rats for 6 weeks. At the end of the study, rats were anesthetized by Ketamine/Xylazine $(0.1 \mathrm{~mL} / 100 \mathrm{~g}$, i.p.) that contained $91 \mathrm{mg} / \mathrm{kg}$ Ketamine and $9.1 \mathrm{mg} / \mathrm{kg}$ Xylazine [9] and then decapitated. After decapitation process, heart and aorta tissues were removed. Biochemical assessments were applied for aorta and heart tissues. The study was approved by the Local Institutional Animal Ethical Committee of Marmara University (with code of 85.2012.mar).

\subsection{Cardiovascular hemodynamic researches}

Measurement of blood pressure of all groups was done from their tails using IITC 229 NIBP (Biopac MP35 Systems, COMMAT Ltd., Ankara, Turkey), at the beginning $\left(t_{1}\right)$ and at the end $\left(t_{2}\right)$ of the study. Rats were placed into $35^{\circ} \mathrm{C}$ cages and waited for 10 minutes in order to acclimate animals. After that, device with pulse sensor was passed to the tail of rats and measurements were taken at least 3 times for each rat. Mean blood pressure was taken and expressed as $\mathrm{mmHg}$. 
Additionally, according to rules of American Society of Echocardiography (ASE), ECHO measurements were done by $12 \mathrm{MHz}$ linear transducer and 5-8 MHz sector transducer (Vivid 3, General Electric Medical Systems Ultrasound, Tirat Carmel, Israel) [10]. Rats were anesthetized by (100 mg/kg, ip) and images from the rats were obtained after at least six heart cycles. These images were taken from parasternal long and short axis by M-mode that were confirmed by two-dimensional images taken from papillary muscle. Left ventricle end-diastolic and end-systolic diameters were measured, and ejection fraction was calculated from the Equation-1 given below.

$$
\% \mathrm{EF}=(\mathrm{LVDd})^{3}-(\mathrm{LVDs})^{3} /(\mathrm{LVDd})^{3} \mathrm{X} 100[11]
$$

\subsection{Isolated tissue bath study in aorta}

Aorta was taken, cleaned and cut into rings $(2 \mathrm{~mm}$ ). It was held in $20 \mathrm{ml}$ Krebs-Henseleit buffer solution with stable temperature of $37^{\circ} \mathrm{C}$ and was continuously aerated with $\left(95 \% \mathrm{O}_{2} ; 5 \% \mathrm{CO}_{2}\right)$ and contractionresponse curves were obtained graphically [12].

\subsection{Determination of nitric oxide (NO) levels in blood}

NO levels in blood was measured by colorimetric kit (Cayman Chemical, Ann Arbor, MI, US). The kit works according to Griess's method based on the conversion of NO metabolites (nitrate into nitrite) with nitrate reductase. Measurement was performed according to the kit procedures. Obtained data was expressed as $\mu \mathrm{mol} / \mathrm{L}$.

\subsection{Biochemical assessments in aorta and heart tissues}

After beheading, tissues were rapidly expunged and immediately put into the formaldehyde solution. Finding of MDA and GSH stages were done by using different methodologies aimed to compare of oxidative tissue damage between all groups [13, 14]. SOD function in the heart and aorta samples was measured conformable to the previously reported method in order to show benefits of exercise and caloric restriction (15). 8-OHdG, which is an indicator of DNA damage, was tested by the kit that purchased from (Oxi Select Oxidative Damage Elisa Kit (STA-320, Cell Biolabs)). DNA closing of from samples was also done by kit (Pure Link ${ }^{\circledR}$ Genomic DNA Mini Kit (K182001, Life Technology)). Finally, Caspase-3 activity and dansity that show the changes in apoptotic structure of tissues were measured by caspase colorimetric attempt kit (Sigma, St. Louis, MO, USA).

\subsection{Western blot protein expression}

Tissues were homogenized in cell lysis buffer $(150 \mathrm{mM} \mathrm{NaCl}, 1 \%$ NP-40 or Triton X-100, $0.5 \%$ sodium deoxycholate, $0.1 \%$ SDS, $50 \mathrm{mM}$ Tris, $\mathrm{pH} 8.0$ ) and centrifuged for $15 \mathrm{sec}$ at $14,000 \mathrm{rpm}$ and $+4^{\circ} \mathrm{C}$. The supernatant was collected, and the protein concentration was determined and cell lysates ( 25 ug protein) were boiled in Laemmli buffer and run on 12\% SDS-PAGE and transposed to nitrocellulose membrane (Santa Cruz Biotechnology). Then, membrane was blocked with 5\% non-fat skim milk powder. Then membrane was probed overnight with primary antibodies (Santa Cruz Biotechnology). For detection HRP conjugated secondary antibodies were used and followed by enhanced chemiluminescence and disclosed to Fuji Super RX film (47410, Tokyo, Japan) to envision the protein bands that examined with imaging system (KODAK, DC290, Analysis and Image System, USA). Information were dissected utilizing Image J Program OD analysis software. On the purpose of a reference protein anti- $\beta$-actin was utilized.

\subsection{Histological examination}

Heart and aorta tissues were fixed in 10\% (v/v) buffered p-formaldehyde and prepared for routine paraffin embedding. Tissues were stained with Hematoxylin and Eosin and assessed with a light microscope (Olympus BX-51). We had limitation at this work that there wasn't a device to quantify the histological recovery when we performed our study.

\subsection{Data analysis}

All data were analyzed with GraphPad Prism 5.0v. (GraphPad Software, San Diego, CA, USA) statistical program, expressed as mean \pm SD (Standard Deviation). One-way Analysis of variance (ANOVA) followed 
by a Bonferroni's Post-test analysis with selected pairs grouped when appropriate or Tukey's Post-test analysis to compare all groups, each other. $\mathrm{P}<0.05$ was considered as statistically significant.

Acknowledgements: The authors would like to thank personnel of Experimental Animal Centre of Marmara University for their supports. This work was not financially supported.

Author contributions: Concept - C.M., G.S., O.E.E.; Design - C.M., G.S.; Supervision - G.S.; Materials - G.S.; Data Collection and/ or Processing - U.V.U., O.D.C.; Analysis and/or Interpretation - C.M., O.D.C., U.V.U., Literature Search - C.M., G.S., O.E.E.; Writing - C.M., O.E.E.; Critical Reviews - C.M., G.S., U.V.U., O.D.C., O.E.E.

Conflict of interest statement: The authors declared no conflict of interest in the manuscript.

Ethics committee approval: The study was approved by the Local Institutional Animal Ethical Committee of Marmara University (with code of 85.2012.mar).

\section{REFERENCES}

[1] Jin K. Modern Biological Theories of Aging. Aging Dis. 2010; 1(2): 72-74.

[2] Fox CS, Larson MG, Leip EP, Culleton B, Wilson PWF, Levy D. Predictors of New-Onset Kidney Disease in a Community-Based Population. JAMA. 2004; 291(7): 844-850. [CrossRef]

[3] Whayne TF, Saha SP, Mukherjee D. Antioxidants in the Practice of Medicine; What Should the Clinician Know? Cardiovasc Hematol Disord Drug Targets. 2016; 16(1): 13-20. [CrossRef]

[4] Lipsky MS, King M. Biological theories of aging. Dis Mon. 2015; 61(11): 460-466. [CrossRef]

[5] Şimşek B, Yanar K, Kansu AD, Belce A, Aydın S, Çakatay U. Caloric restriction improves the redox homeostasis in the aging male rat heart even when started in middle-adulthood and when the body weight is stable. Biogerontology. 2019; 20(1): 127-140. [CrossRef]

[6] Montenegro ML, Bonocher CM, Meola J, Portella RL, Ribeiro-Silva A, Brunaldi MO, Ferriani RA, Rosa-E-Silva JC. Effect of Physical Exercise on Endometriosis Experimentally Induced in Rats. Reprod Sci. 2019; 26(6): 1933719118799205. [CrossRef]

[7] Gobatto CA, de Mello MA, Sibuya CY, de Azevedo JR, dos Santos LA, Kokubun E. Maximal lactate steady state in rats submitted to swimming exercise. Comp Biochem Physiol A Mol Integr Physiol. 2001; 130(1): 21-27. [CrossRef]

[8] Liu W, Xu Y, Lu J, Zhang Y, Sheng H, Ni X. Swimming exercise ameliorates depression-like behaviors induced by prenatal exposure to glucocorticoids in rats. Neurosci Lett. 2012 Aug 30; 524(2): 119-123. [CrossRef]

[9] The University of Iowa Vertebrate Animal Research Anesthesia (Guideline) https://animal.research.uiowa.edu/iacuc-guidelines-anesthesia (accessed on July 18th, 2018).

[10] Schiller NB, Shah PM, Crawford M, DeMaria A, Devereux R, Feigenbaum H, Gutgesell H, Reichek N, Sahn D, Schnittgeet I. Recommendations for quantitation of the left ventricle by two-dimensional echocardiography. American Society of Echocardiography Committee on Standards, Subcommittee on Quantitation of TwoDimensional Echocardiograms. J of Am Soc Echocardiogr. 1989; 2(5): 358-367. [CrossRef]

[11] Bonagura JD. M-mode echocardiography: Basic principles. Vet Clin North Am Small Anim Pract. 1983; 13(2): 299320. [CrossRef]

[12] Paskaloğlu K, Şener G, Ayanoğlu-Dülger G. Melatonin treatment protects against diabetes-induced functional and biochemical changes in rat aorta and corpus cavernosum. Eur J Pharmacol. 2004; 499(3): 345-354. [CrossRef]

[13] Buege JA, Aust SD. Microsomal lipid peroxidation. Methods. Enzymol. 1978; 52: 302-310. [CrossRef]

[14] Mergel D, Andermann G, Andermann C. Simultaneous spectrophotometric determination of oxidized and reduced glutathione in human and rabbit red cells. Methods. Find Exp Clin Pharmacol. 1979; 1(5): 277-283.

[15] Mylroie AA, Collins H, Umbles C, Kyle J. Erythrocyte superoxide dismutase activity and other parameters of copper status in rats ingesting lead acetate. Toxicol Appl Pharmacol. 1986; 82(3): 512-520. [CrossRef]

[16] García-Prieto CF, Pulido-Olmo H, Ruiz-Hurtado G, Gil-Ortega M, Aranguez I, Rubio MA, Ruiz-Gayo M, Somoza B, Fernández-Alfonso MS. Mild caloric restriction reduces blood pressure and activates endothelial AMPK-PI3K-AkteNOS pathway in obese Zucker rats. Vascul Pharmacol. 2015; 65-66: 3-12. [CrossRef]

[17] Normandin E, Chmelo E, Lyles MF, Marsh AP, Nicklas BJ. Effect of Resistance Training and Caloric Restriction on the Metabolic Syndrome. Med. Sci. Sports Exerc. 2017; 49(3): 413-419. [CrossRef] 
[18] Campos JC, Fernandes T, Bechara LR, da Paixão NA, Brum PC, de Oliveira EM, Ferreira JC. Increased clearance of reactive aldehydes and damaged proteins in hypertension-induced compensated cardiac hypertrophy: impact of exercise training. Oxid Med Cell Longev. 2015; 2015: 464195. [CrossRef]

[19] Cardoso AM, Abdalla FH, Bagatini MD, Martins CC, Zanini D, Schmatz R, Jaques JA, Leal DB, Morsch VM, Schetinger MR. Swimming training prevents alterations in ecto-NTPDase and adenosine deaminase activities in lymphocytes from $\mathrm{N} \omega$-nitro-L-arginine methyl ester hydrochloride induced hypertension rats. J Hypertens. 2015; 33(4): 763-772. [CrossRef]

[20] Ruiz-Hurtado G, García-Prieto CF, Pulido-Olmo H, Velasco-Martín JP, Villa-Valverde P, Fernández-Valle ME, Boscá L, Fernández-Velasco M, Regadera J, Somoza B, Fernández-Alfonso MS. Mild and Short-Term Caloric Restriction Prevents Obesity-Induced Cardiomyopathy in Young Zucker Rats without Changing in Metabolites and Fatty Acids Cardiac Profile. Front Physiol. 2017; 8(42): 22-31. [CrossRef]

[21] Pagan LU, Damatto RL, Cezar MD, Lima AR, Bonomo C, Campos DH, Gomes MJ, Martinez PF, Oliveira SA Jr, Gimenes R, Rosa CM, Guizoni DM, Moukbel YC, Cicogna AC, Okoshi MP, Okoshi K. Long-term low intensity physical exercise attenuates heart failure development in aging spontaneously hypertensive rats. Cell Physiol Biochem. 2015; 36(1): 61-74. [CrossRef]

[22] Paulino EC, Ferreira JC, Bechara LR, Tsutsui JM, Mathias W Jr, Lima FB, Casarini DE, Cicogna AC, Brum PC, Negrão $\mathrm{CE}$. Exercise training and caloric restriction prevent reduction in cardiac $\mathrm{Ca} 2+$-handling protein profile in obese rats. Hypertension. 2010; 56(4): 629-635. [CrossRef]

[23] Collins C., Tzima E. Hemodynamic forces in endothelial dysfunction and vascular aging. Exp Gerontol. 2011; 46(23): 185-188. [CrossRef]

[24] Green DJ, Jones H, Thijssen D, Cable NT, Atkinson G. Flow-mediated dilation and cardiovascular event prediction: does nitric oxide matter? Hypertension. 2011; 57(3): 363-369. [CrossRef]

[25] Gu Q, Wang B, Zhang XF, Ma YP, Liu JD, Wang XZ. Chronic aerobic exercise training attenuates aortic stiffening and endothelial dysfunction through preserving aortic mitochondrial function in aged rats. Exp Gerontol. 2014; 56: 37-44. [CrossRef]

[26] Zanetti M, Gortan Cappellari G, Burekovic I, Barazzoni R, Stebel M, Guarnieri G. Caloric restriction improves endothelial dysfunction during vascular aging: Effects on nitric oxide synthase isoforms and oxidative stress in rat aorta. Exp Gerontol. 2010; 45(11): 848-855. [CrossRef]

[27] Rippe C, Lesniewski L, Connell M, LaRocca T, Donato A, Seals D. Short-term calorie restriction reverses vascular endothelial dysfunction in old mice by increasing nitric oxide and reducing oxidative stress. Aging Cell. 2010; 9(3): 304-312. [CrossRef]

[28] Shinmura K. Cardiovascular protection afforded by caloric restriction: essential role of nitric oxide synthase. Geriatr Gerontol Int. 2011; 11(2): 143-156. [CrossRef]

[29] Vina J, Borras C, Gomez-Cabrera MC, Orr WC. Part of the series: from dietary antioxidants to regulators in cellular signalling and gene expression. Role of reactive oxygen species and (phyto)oestrogens in the modulation of adaptive response to stress. Free Radic Res. 2006; 40(2): 111-119. [CrossRef]

[30] Claudino MA, Delbin MA, Franco-Penteado CF, Priviero FB, De Nucci G, Antunes E, Zanesco A. Exercise training ameliorates the impairment of endothelial and nitrergic corpus cavernosum responses in diabetic rats. Life Sci. 2011; 88(5-6): 272-277. [CrossRef]

[31] Alugoju P, V K D KS, Periyasamy L. Effect of Short-term Quercetin, Caloric Restriction and Combined Treatment on Age-related Oxidative Stress Markers in the Rat Cerebral Cortex. CNS Neurol Disord Drug Targets. 2018; 17(2): 119131. [CrossRef]

[32] Ji LL, Fu R. Responses of glutathione system and antioxidant enzymes to exhaustive exercise and hydroperoxide. J Appl Physiol. 1992; 72(2): 549-554. [CrossRef]

[33] Walsh ME, Shi Y, Van Remmen H. The effects of dietary restriction on oxidative stress in rodents. Free Radic Biol Med. 2014; 66: 88-99. [CrossRef]

[34] Ning YC, Cai GY, Zhuo L, Gao JJ, Dong D, Cui S, Feng Z, Shi SZ, Bai XY, Sun XF, Chen XM. Short-term calorie restriction protects against renal senescence of aged rats by increasing autophagic activity and reducing oxidative damage. Mech Ageing Dev. 2013; 134(11-12): 570-579. [CrossRef]

[35] Singh S, Singh AK, Garg G, Rizvi SI. Fisetin as a caloric restriction mimetic protects rat brain against aging induced oxidative stress, apoptosis and neurodegeneration. Life Sci. 2018; 193: 171-179. [CrossRef] 
[36] Gomes MJ, Martinez PF, Pagan LU, Damatto RL, Cezar MDM, Lima ARR, Okoshi K, Okoshi MP. Skeletal muscle aging: influence of oxidative stress and physical exercise. Oncotarget. 2017; 8(12): 20428-20440. [CrossRef]

[37] Ristow M, Zarse K, Oberbach A, Kloting N, Birringer M, Kiehntopf M, Stumvoll M, Kahn CR, Blüher M. Antioxidants prevent health-promoting effects of physical exercise in humans. Proc Natl Acad Sci USA. 2009; 106(21): 8665-8670. [CrossRef]

[38] Seo H, Lee NH, Ryu S. Antioxidant and antiapoptotic effects of pine needle powder ingestion and endurance training in high cholesterol-fed rats. J Exerc Nutrition Biochem. 2014; 18(3): 301-309.

[39] López-Domínguez JA, Khraiwesh H, González-Reyes JA, López-Lluch G, Navas P, Ramsey JJ, de Cabo R, Burón MI, Villalba JM. Dietary fat modifies mitochondrial and plasma membrane apoptotic signaling in skeletal muscle of calorie-restricted mice. Age (Dordr). 2013; 35(6): 2027-2044. [CrossRef]

[40] Chopek JW, Gardiner PF. Life-long caloric restriction: Effect on age-related changes in motoneuron numbers, sizes and apoptotic markers. Mech Ageing Dev. 2010; 131(10): 650-659. [CrossRef]

[41] Ahmet I, Tae HJ, de Cabo R, Lakatta EG, Talan MI. Effects of calorie restriction on cardioprotection and cardiovascular health. J Mol Cell Cardiol. 2011; 51(2): 263-271. [CrossRef]

This is an open access article which is publicly available on our journal's website under Institutional Repository at http://dspace.marmara.edu.tr. 